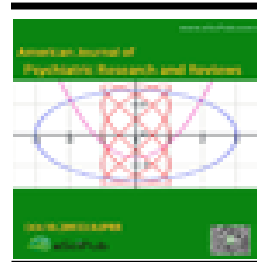

American Journal of Psychiatric Research and Reviews (ISSN:2637-479X)

\title{
ABSENTEEISM DUE TO MENTAL DISORDERS IN A MUNICIPALITY IN THE INTERIOR OF ALAGOAS
}

\section{Verônica de Medeiros Alves ${ }^{2}$. Francisco, Leilane Camila Ferreira de Lima.}

${ }^{1}$ Especialista em Psiquiatria e Saúde Mental (Residência UNCISAL), Mestranda em Enfermagem (UFAL). ${ }^{2}$ Docente do curso de Enfermagem da Universidade Federal de Alagoas, Mestre em Ciências da Saúde, Doutora em Saúde Mental pelo Instituto de Psiquiatria da UFRJ.

\section{ABSTRACT}

Introduction: Work-related diseases cause high absenteeism rates and their occurrence has been increasing gradually and because they cause great impact on the economy of the countries. Objective: To identify the prevalence of absenteeism due to mental disorders in servers in the municipality of Arapiraca-AL, from January to December 2013. Methodology: This is a descriptive, cross-sectional study with a quantitative approach. For this, we analyzed all the records used in the situation of work clearance of the municipal servants of Arapiraca in the Medical Board. Results: The study subjects were 816 public servants from the municipality of Arapiraca-AL, away from work from January to December 2013. For data analysis, the Statistical Package for the Social Sciences-SPSS (version 20) was used. The present study showed that most professionals away from work were female (693-84.9\%), married (426 - 52.2\%), lived in rural areas (116 - 14.2\%) and were permanent employees $(627-76.8 \%)$. Education configured the stocking organ most affected by absenteeism at work (474 $-58.1 \%)$ represented by the post of teacher $(281-34.4 \%)$. The absence of mental disorders occupied the fourth most frequent cause $(151$ - 18.5\%) among the various reasons for distancing from work and the depressive episode was the mental disorder that stood out in relation to the others $(19-12.6 \%)$. Conclusion: The high rate of absenteeism due to mental disorders evidences the need for a new look at the mental health of workers in order to develop strategies for immediate intervention.

\section{${ }^{*}$ Correspondence to Author:}

Verônica de Medeiros Alves Docente do curso de Enfermagem da Universidade Federal de Alagoas, Mestre em Ciências da Saúde, Doutora em Saúde Mental pelo Instituto de Psiquiatria da UFRJ.

\section{How to cite this article:}

Verônica de Medeiros Alves. Francisco, Leilane Camila Ferreira de Lima.ABSENTEEISM DUE TO MENTAL DISORDERS IN A MUNICIPALITY IN THE INTERIOR OF ALAGOAS.American Journal of Psychiatric Research and Reviews, 2020, 3:17

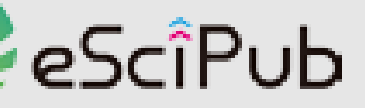

eSciPub LLC, Houston, TX USA. Website: https://escipub.com/

Keywords: Mental Health, Worker's Health, Absenteeism. 


\section{INTRODUCTION}

In the midst of technological advancement and scientific knowledge, the work should have a series of characteristics that bring the welfare and quality of life of the worker, such as the reduction of working hours and social insertion. However, what is seen is the work that, most of them, brings the social precarization and the illness ${ }^{1}$. This illness is referred to as work-related diseases, which are a set of damages that affect the health of the worker, originated or aggravated by risk factors arising from the work environment itself2.

Work-related illnesses cause high absenteeism rates. This has been the target of attention, due to the fact that its occurrence has been increasing gradually and because they cause a great impact on the economy of the countries ${ }^{3}$. Only in the 2012 year, Social Security released almost 5 million of benefits and the total value of these was 4.53 billion, representing an increase of $14 \%$ in relation to the 2011 year. Among the benefits of $2012,45.8 \%$ was due to disease-aid ${ }^{4}$.

In the midst of the main diseases related to work, Mental Disorders (MD) have reached a large portion of the population, generating absenteeism and prolonged removal of their activities. A study conducted in São Paulo revealed a high prevalence of absenteeism due to MD and, in particular, depressive patients ${ }^{5}$. Seeking to investigate the reasons for distancing from mental disorders, Miranda, Alvarado and Kaufman $^{6}$ observed that the most present diagnoses were depressive disorders and behavior, followed by anxious disorders. All this can be the result of the stressful factors that the professional experiences, as well as, due to the increased demand of high complexity services, thus generating pressure by production ${ }^{7}$.

There is a precariousness regarding epidemiological researches addressing the issue of absenteeism among public servants in Brazil. The same happens with the municipality of Arapiraca, which makes it more difficult to know the dimension of the problem, as well as the definition of priorities for the planning, implementation and evaluation of actions aimed at improving the health of the worker ${ }^{7}$.

\section{OBJECTIVE}

To identify the prevalence of absenteeism due to mental disorders of the servants of the municipality of Arapiraca-AL, according to the International Classification of Diseases (ICD10), from January to December 2013.

\section{METHODOLOGY}

This is a descriptive, cross-sectional study with a quantitative approach, based on the documental analysis of the data from the absenteeism of the servants provided by the Medical Board of the Arapiraca city. The study subjects were 816 public servants from Arapiraca-AL, away from work in the period from January to December of 2013.

The instrument of data collection: the study used secondary data found in the records used in situations of absenteeism of the municipal servants of Arapiraca, with no need to use the Term of Free and Clarified Consent (TFCC).

Data collection was performed by the main researcher and collaborating students. For this, we used the diary book of absenteeism of the Medical Board, the records of the servers that drifted away and the digital system of Arapiraca city that contained complementary information about them. Subsequently, the data were stored, tabulated, analyzed and interpreted.

\section{RESULTS}

A total of 816 absences from work were identified for different reasons in 2013. The mean general age was $40.9 \pm 10.5$ years, while in female employees it was $40.5 \pm 10.3$ years and in males, $43.0 \pm 11.3$ years, with regard to absenteeism in general. In the absenteeism due to mental disorder, the mean general age was $42.2 \pm 9.3$ years, in females $44.2 \pm 9.8$ years and in males $44.2 \pm 5.0$ years.

Regarding gender, 693 (84.9\%) females and $123(15.1 \%)$ males were removed from work for general reasons. Regarding mental disorders, 
$119(14.6 \%)$ absenteeism were identified, being $104(87.4 \%)$ females and 15 (12.6\%) males.

Evaluating the employment of employees in general, we identified that $189(23.2 \%)$ of the people who left were hired and 627 (76.8\%) effective. Of these, 8 (6.7\%) were hired and 111 $(93.3 \%)$ were removed from work for mental disorders.

Regarding marital status, 286 (35\%) were single and $426(52.2 \%)$ were married in the general absence. Among those on mental illness, 41 $(34.5 \%)$ were single and $54(45.4 \%)$ were married (Table 1).

It was observed that the employees who lived in Arapiraca had a higher frequency of absence from work in general (736 - 90.2\%) (Table 1).

The departments with the highest frequencies of absence from work in general and for mental disorders were Education and Health. Regarding the absences in general, the frequencies were: Education (474 - 58.1\%), Health (244 - 29.9\%), Cleaning and Public Lighting (66 - 8.1\%) and Administration (17 $2.1 \%)$. Regarding sick leave, the frequencies were: Education $(81-68.1 \%)$, Health (32 26.9\%), Cleaning and Public Lighting (2 - 1.7\%) and Administration (4 - 3,4\%) (Table 2).

The professionals who were most often moved away were teachers $(281-34.4 \%)$. Secondly, the Administrative Service Assistants (117 $14.3 \%$ ) were found. Thirdly, there were community health agents $(61-7.5 \%)$. The Garis $(59-7.2 \%)$ and General Service Assistants (50 - 6.1\%), also presented relevant absenteeism frequencies. Verifying the absenteeism due to mental disorders, the first position was also occupied by the teachers $(56-47.0 \%)$. Next were the Administrative Service Assistants (19$16.0 \%)$, the Community Health agents (12 $10.1 \%)$ and General Service Assistants (8 $6.7 \%$ ) (Table 2).

It was found that $259(31.7 \%)$ professionals generally left for a period of up to 15 days, while $232(28.4 \%)$ remained 30 days apart and 149 $(18.4 \%)$ stayed longer 90 days. Analyzing the absenteeism due to mental disorders, 48 $(40.3 \%)$ occurred for a period of 30 days, 22 (18.5\%) for 60 days and 20 (16.8\%) for up to 15 days (Table 2).

Regarding the various cases of absenteeism among professionals in Arapiraca city, the first place was occupied by reason of pregnancy, childbirth and puerperium (180 - 22.1\%). Then, absenteeism was presented to accompany a sick family member or to take leave to supervise physical illness or risk pregnancy (167 - 20.5\%). Third place was related to musculoskeletal system diseases (166 - 20.3), while mental and behavioral disorders occupied the fourth position (151 - 18.5\%) (Table 4).

Regarding the main CID-10 groups on mental and behavioral disorders, the most important were neurotic, stress-related and somatoform disorders (73 - 48.3\%), followed by affective mood disorders (67 - 44.4\%) (Table 4).

Regarding mental and behavioral disorders, more specifically, severe depressive episodes without psychotic symptoms were found in the first position (19-12.6\%). These belong to the group of mood disorders. Then there were mixed anxiety and depressive disorders (15 - 9.9\%), panic disorders $(12-7.9 \%)$ and acute reaction to stress (12-7.9\%), all of which belong to the group of neurotic disorders, related to stress and somatoforms.

\section{DISCUSSION}

This study showed the frequency of absence from work due to mental disorders in the different professional categories in servers in the municipality of Arapiraca-AL. A similar study carried out in Vitória, Espirito Santo, by Andrade et $\mathrm{al}^{8}$, at analyzing 400 medical records, verified 301 general absenteeism. Arapiraca has approximately 214,006 inhabitants and Vitória has a population of $327,801^{9}$. Our study, when comparing with this and observing that Arapiraca presents a smaller population, proves that there is a high rate of absence from work in this city and it is seen how alarming this prevalence is. 
As for the age group, a study showed that the mean age was 47 years, with a variation of 8 years for more or less ${ }^{7}$. The research that most closely resemed ours was that of Silva el at $1^{10}$, who found a greater predominance of clearance between 40 and 49 years. While in our study, the average general age was 40.9 years, varying from 10.5 years to more or less.

Another study identified a mean age of 45.1 years with a standard deviation of 10 , where women had a mean age of $44.9 \pm 9.8$ and men of $45.8 \pm 10.4^{11}$. Our study found a mean of 40.5 \pm 10.3 years in females and $43.0 \pm 11.3$ years in males. Although these studies present little difference of years in relation to the mean age, it is perceived that in our study the clearings occurred earlier. This leads us to believe that they are, consequently, getting sick early. It is observed that there is a relationship between increasing age and susceptibility to illness due to the changes that aging provides ${ }^{12}$.

A research conducted by Leão et al. ${ }^{13}$, seeking to analyze the licenses granted by the Medical Board of the municipality of Goiania between the years 2005 and 2010, verified a higher prevalence among women. Other studies also show a predominance of females among the clearings, corroborating the findings of our study ${ }^{14,10.7,6 .}$.

A study conducted by Becker and Oliveira ${ }^{15}$, in Manaus, identified that effective professionals were more absent at work than those hired, similar to our study. This is probably due to the stability that an effective position brings to the employee. The contractor is the holder of the fear of dismissal while he is away from employment ${ }^{15}$.

A study by Fonseca and Carlotto ${ }^{7}$ with public servants from Porto Alegre verified that the majority of those who moved away are single or separate, which differs from our study, which showed a higher prevalence among those with marital status. On the other hand, Costa, Vieira and Sena ${ }^{16}$ affirmed that, among the professionals studied, the married people had a higher frequency of distancing from work, agreeing with our study. This fact may also be related to the burden that a family brings, such as problems and responsibility ${ }^{17}$.

A study conducted in the city of Porto Alegre verified that the Municipal Secretariat of Education (MSE) was responsible for the largest number of licenses for health treatment and the Municipal Health Secretariat (MHE) occupied the second position ${ }^{18}$. This corroborates our study. Leão et al. ${ }^{13}$ also found that, among the positions, the teacher had a higher frequency of distancing from work, being in agreement with our study.

This can happen due to the fact that teachers undergo a very large workload, which goes far beyond the period in which they are in the place where they work. They still need to prepare classes, correct works and exams, among other activities assigned to them ${ }^{19}$. These are risk factors for the illness and, consequently, for absenteeism at work.

A cross-sectional study conducted in Minas Gerais verified the causes of absenteeism for five consecutive years and concluded that the diseases of the musculoskeletal system were highlighted and then the mental and behavioral disorders, but that in the course of time the MD number was increasing much more compared to musculoskeletal disorders ${ }^{20}$.

With regard to the main CID-10 groups on mental and behavioral disorders, a study conducted with state public servants in Alagoas found that most of the clearings $(1015-61 \%)$ were given by mood disorders, followed by neurotic disorders related to "stress" and Somatoform disorders $(440-26.4 \%)^{10}$, contradicting our study, which showed a higher prevalence of neurotic disorders related to "stress" and Somatoform disorders (73 $48.3 \%)$, followed by $(67-44.4 \%)$ of displacements due to mood disorders.

It should be observed that, by separating the disorders more specifically, the depressive disorders, which belong to the group of mood disorders, stood out in relation to the others. This 
corroborates with a research conducted in the city of São Paulo, which verified the depressive disorders with a greater proportion in relation to the others ${ }^{5}$. Other studies confirm this finding $21,18,6$.

\section{CONCLUSION}

The present study shows that most professionals away from work are female, married, reside in the rural area and and were permanent employees. Education configures the stocking organ most affected by absenteeism in the work represented by the teachers, both for the reason of mental disorders and for the other clinical diseases.

The absence due to mental disorders occupied the fourth most frequent cause among the various reasons for leaving work and the depressive episode was the mental disorder that stood out in relation to the others, followed by mixed anxious and depressive disorders.

Studies of this character are extremely important because they allow the situational diagnosis of the absenteeism between the public servants and, therefore, to be rethought ways to mitigate the problem.

Table 1. General data of professionals away from work in the municipality of Arapiraca from January to December 2013, Alagoas, Brazil - 2013.

\begin{tabular}{|c|c|c|c|c|}
\hline Average (sd) age & Average age & Standard deviation (SD) & Average age & Standard deviation (SD) \\
\hline General & 40,9 & 10,5 & 42,2 & 9,3 \\
\hline Female & 40,5 & 10,3 & 44,2 & 9,8 \\
\hline Male & 43,0 & 11,3 & 44,2 & 5,0 \\
\hline \multirow[t]{2}{*}{ Sex } & \multicolumn{2}{|c|}{ Absenteeism in general } & \multicolumn{2}{|c|}{ Absenteism due to mental disorders } \\
\hline & $\begin{array}{l}\text { Frequency } \\
\text { (N) }\end{array}$ & Percentage (\%) & $\begin{array}{l}\text { Frequency } \\
\text { (N) }\end{array}$ & Percentage (\%) \\
\hline Female & 693 & 84,9 & 104 & 87,4 \\
\hline Male & 123 & 15,1 & 15 & 12,6 \\
\hline TOTAL & 816 & 100,0 & 119 & 100,0 \\
\hline Employment & $\begin{array}{l}\text { Frequency } \\
\text { (N) }\end{array}$ & Percentage (\%) & $\begin{array}{l}\text { Frequency } \\
\text { (N) }\end{array}$ & Percentage (\%) \\
\hline Contracted & 189 & 23,2 & 8 & 6,7 \\
\hline Permanent employees & 627 & 76,8 & 111 & 93,3 \\
\hline TOTAL & 816 & 100,0 & 119 & 100,0 \\
\hline Marital status & $\begin{array}{l}\text { Frequency } \\
\text { (N) }\end{array}$ & Percentage (\%) & $\begin{array}{l}\text { Frequency } \\
\text { (N) }\end{array}$ & Percentage (\%) \\
\hline Single & 286 & 35,0 & 41 & 34,5 \\
\hline Married & 426 & 52,2 & 54 & 45,4 \\
\hline Disvorciated & 30 & 3,7 & 5 & 4,2 \\
\hline Widower & 26 & 3,2 & 6 & 5,0 \\
\hline No response & 48 & 5,9 & 13 & 10,9 \\
\hline TOTAL & 816 & 100,0 & 119 & 100,0 \\
\hline \multirow[t]{2}{*}{ Municipality } & \multicolumn{2}{|c|}{ Absenteeism in general } & \multicolumn{2}{|c|}{ Absenteism due to mental disorders } \\
\hline & $\begin{array}{l}\text { Frequency } \\
\text { (N) }\end{array}$ & Percentage (\%) & $\begin{array}{l}\text { Frequency } \\
\text { (N) }\end{array}$ & Percentage (\%) \\
\hline Arapiraca & 736 & 90,2 & 105 & 88,2 \\
\hline Other & 48 & 5,9 & 5 & 4,2 \\
\hline No response & 32 & 3,9 & 9 & 7,6 \\
\hline TOTAL & 816 & 100,0 & 119 & 100,0 \\
\hline
\end{tabular}

Source: Research Data, 2015. * Municipalities that presented leave of absence equal to 1 for the overall departures and for the removals by mental disorders. 
Table 2. Frequency of absenteeism of workers from the municipality of Arapiraca by a stocking organ from January to December 2013, Alagoas, Brazil - 2013.

\begin{tabular}{|c|c|c|c|c|}
\hline \multirow[t]{2}{*}{ Stocking organ } & \multicolumn{2}{|c|}{ Absenteeism in general } & \multicolumn{2}{|c|}{ Absenteism due to mental disorders } \\
\hline & $\begin{array}{l}\text { Frequency } \\
\text { (N) }\end{array}$ & Percentage (\%) & $\begin{array}{l}\text { Frequency } \\
\text { (N) }\end{array}$ & Percentage (\%) \\
\hline Education & 474 & 58,1 & 81 & 68,1 \\
\hline Health & 244 & 29,9 & 32 & 26,9 \\
\hline${ }^{*}$ SELIP & 66 & 8,1 & 2 & 1,7 \\
\hline Administration & 17 & 2,1 & 4 & 3,4 \\
\hline ** Other & 15 & 1,8 & 0 & - \\
\hline TOTAL & 816 & 100,0 & 119 & 100,0 \\
\hline \multirow[t]{2}{*}{ Function } & \multicolumn{2}{|c|}{ Absenteeism in general } & \multicolumn{2}{|c|}{ Absenteism due to mental disorders } \\
\hline & $\begin{array}{l}\text { Frequency } \\
\text { (N) }\end{array}$ & Percentage (\%) & $\begin{array}{l}\text { Frequency } \\
\text { (N) }\end{array}$ & Percentage (\%) \\
\hline Teacher & 281 & 34,4 & 56 & 47,0 \\
\hline Administrative services assistant & 117 & 14,3 & 19 & 16,0 \\
\hline Community Health Agent & 61 & 7,5 & 12 & 10,1 \\
\hline Gari & 59 & 7,2 & 2 & 1,7 \\
\hline General Services Assistant & 50 & 6,1 & 8 & 6,7 \\
\hline Administrative Assistant & 32 & 3,9 & 2 & 1,7 \\
\hline Nursing Assistant & 25 & 3,1 & 3 & 2,5 \\
\hline Endemias Agent & 24 & 2,9 & 2 & 1,7 \\
\hline Nurse & 16 & 2,0 & 2 & 1,7 \\
\hline Surveillance agente & 14 & 1,7 & 2 & 1,7 \\
\hline Dentist & 14 & 1,7 & 0 & - \\
\hline Administrative agente & 13 & 1,6 & 1 & 0,8 \\
\hline Auxiliary Room & 11 & 1,4 & 0 & - \\
\hline Nursing Technician & 11 & 1,4 & 1 & 0,8 \\
\hline Psychologist & 10 & 1,2 & 2 & 1,7 \\
\hline${ }^{*}$ Other & 78 & 9,6 & 7 & 5,9 \\
\hline TOTAL & 816 & 100,0 & 119 & 100,0 \\
\hline
\end{tabular}

Source: Search data, 2015.

* Secretariat for cleaning and public lighting

* * Secretariats that showed a frequency of absence from work less than 10 for the removals in general.

Table 3. Frequency of absenteeism days of public servants in the municipality of Arapiraca from January to December 2013, Alagoas, Brazil - 2013.

\begin{tabular}{|c|c|c|c|c|}
\hline \multirow[t]{3}{*}{ Days of absenteeism } & \multicolumn{2}{|c|}{ Absenteeism in general } & \multicolumn{2}{|c|}{ Absenteism due to mental disorders } \\
\hline & Frequency & Percentage (\%) & $\begin{array}{l}\text { Frequency } \\
\text { (N) }\end{array}$ & Percentage (\%) \\
\hline & (N) & & & \\
\hline Up to 15 Days & 259 & 31,7 & 20 & 16,8 \\
\hline 30 Days & 232 & 28,4 & 48 & 40,3 \\
\hline 60 Days & 99 & 12,1 & 22 & 18,5 \\
\hline 90 Days & 77 & 9,4 & 18 & 15,1 \\
\hline More than 90 Days & 149 & 18,4 & 11 & 9,2 \\
\hline TOTAL & 816 & 100,0 & 119 & 100,0 \\
\hline
\end{tabular}

Source: Search data, 2015. 
Table 4. Reasons for removal from work according to CID-10 in public servants of the municipality of Arapiraca from January to December 2013, Alagoas, Brazil - 2013.

\begin{tabular}{|c|c|c|}
\hline Removal from work & $\begin{array}{l}\text { Frequency } \\
\text { (N) }\end{array}$ & Percentage (\%) \\
\hline Pregnancy, childbirth and puerperium & 180 & 22,1 \\
\hline Follow-up of sick family or withdrawal for supervision of physical illness or pregnancy at risk & 167 & 20,5 \\
\hline Diseases of the musculoskeletal system & 166 & 20,3 \\
\hline Mental and behavioral disorders & 151 & 18,5 \\
\hline Injuries and other consequences of external causes & 64 & 7,8 \\
\hline Diseases of the circulatory system & 61 & 7,5 \\
\hline Neoplasms [Tumors] & 52 & 6,4 \\
\hline Genitourinary Tract Diseases & 40 & 4,9 \\
\hline Digestive tract Diseases & 38 & 4,7 \\
\hline Some infectious and parasitic diseases & 29 & 3,6 \\
\hline Nervous system diseases & 28 & 3,4 \\
\hline Eye Diseases and Attachments & 28 & 3,4 \\
\hline Respiratory tract Diseases & 26 & 3,2 \\
\hline * Other & 31 & 3,8 \\
\hline TOTAL & 816 & 100,0 \\
\hline Mental disorders & $\begin{array}{l}\text { Frequency } \\
\text { (N) }\end{array}$ & Percentage (\%) \\
\hline Neurotic disorders related to Stress and somatoform & 73 & 48,3 \\
\hline Affective Mood Disorders & 67 & 44,4 \\
\hline Schizophrenia, schizotypic and delusional disorders & 3 & 2,0 \\
\hline Organic Mental Disorders & 2 & 1,3 \\
\hline Behavioral syndromes & 2 & 1,3 \\
\hline Disorders related to the use of psychoactive substance & 1 & 0,7 \\
\hline Mental retardation & 1 & 0,7 \\
\hline Disorders of psychological development & 1 & 0,7 \\
\hline Unspecified Mental disorder & 1 & 0,7 \\
\hline TOTAL & 151 & 100,0 \\
\hline
\end{tabular}

Source: Search data, 2015. ${ }^{*}$ Motives with frequency less than 15.

\section{REREFENCES}

1. FRANCO, T.; DUCK, G.; SELIGMANN-SILVA, E. As novas relações de trabalho, o desgaste mental do trabalhador e os transtornos mentais no trabalho precarizado. Revista Brasileira de Saúde Ocupacional, São Paulo, v. 35, n. 122, p. 229248, 2010.
2. BRASIL. Ministério da Saúde. Secretaria de Políticas de Saúde. Saúde do Trabalhador. Brasília, DF, 2001. 66p.

3. SANCINETTI, T. R. et al. Absenteísmo - doença na equipe de enfermagem: relação com a taxa de ocupação. Revista Esc Enferm USP, São Paulo, v. 43, n. 2, p. 1277-1283, 2009.

4. Brasil. Ministério da Previdência Social. Secretaria de Políticas de Previdência Social. Anuário estatístico da previdência social. Brasília, DF, 2012. 886p. 
5. CRUZ, C. R. B. et al. Transtornos mentais como causa de absenteísmo entre servidores públicos em São Paulo. Revista Psiquiatria Clínica, São Paulo, v. 38, n. 6, p. 265-266, 2011.

6. MIRANDA, G.; ALVARADO, E.; KAUFMAN, J. S. Duración de las licencias médicas FONASA por transtornos mentales y del comportamento. Revista Medica de Chile, Chile, v. 40, p. 207-213, 2012.

7. FONSECA, R. M. C.; CARLOTTO, M. S. Saúde mental e afastamento do trabalho em servidores do judiciário do Rio Grande do Sul. Psicologia em pesquisa, Juiz de Fora, v. 7, n. 2, p. 117-125, 2011.

8. ANDRADE, T. B. et al. Prevalência de absenteísmo entre trabalhadores do serviço público. Scientia Medica, Porto Alegre, v. 18, n. 4, p. 166-171, 2008.

9. IBGE. Censo Demográfico - 2010. Disponível em:

<http://www.cidades.ibge.gov.br/xtras/temas.php ?lang $=\&$ codmun $=270030$ \&idtema $=79 \&$ search $=a l$ agoas\%7Carapiraca\%7Ccenso-demografico2010:-resultados-do-universo-indicadoressociais-municipais--.> Acesso em: 20 jul. 2015.

10. SILVA, E. B. F. et al. Transtornos mentais e comportamentais: perfil dos afastamentos de servidores públicos estaduais em Alagoas, 2009. Epidemiologia Serv. Saúde, Brasília, v. 21, n. 3, p. 505-514, 2012.

11. SALA, A. et al. Licenças médicas entre trabalhadores da Secretaria de Estado da Saúde de São Paulo no ano de 2004. Caderno de Saúde Pública, Rio de Janeiro, v. 25, n. 10, p. 21682178, 2009.

12. BARBOSA-BRANCO, A.; SOUZA, W. R.; STEENSTRA, I. A. Incidence of work and nonwork related disability claims in Brazil. American Journal of Industrial Medicine, New York, v. 54, p. 858-871, 2011.

13. LEÃO, A. L. M. et al. Absenteísmo-doença no serviço público municipal de Goiânia. Revista Brasileira de Epidemiologia, São Paulo, v. 18, n. 1, p. 262-277, 2015.

14. FLACH, P. A. et al. Factors associated with first return to work and sick leave durations in workers with common mental disorders. European Journal of Public Health, Stockholm, v. 22, n. 3, p. 440445, 2011.

15. BECKER, S. G.; OLIVEIRA, M. L. C. Estudo do absenteísmo dos profissionais de enfermagem de um centro psiquiátrico em Manaus, Brasil. Revista Latino-Americana de Enfermagem, Ribeirão Preto, v. 16, n. 1, p. 1-7, 2008.

16. COSTA, F. M.; VIEIRA, M. A.; SENA, R. R. Absenteísmo relacionado a doenças entre membros da equipe de enfermagem de um hospital escola. Revista Brasileira de Enfermagem, Brasília, v. 62, n. 1, p. 38-44, 2009.

17. ALVES, M.; GODOY, S. C. B. Procura pelo serviço de atenção à saúde do trabalhador $\mathrm{e}$ absenteísmo doença em um hospital universitário. Revista Mineira de Enfermagem, Minas Gerais, v. 5, n. 1, p. 73-81, 2001.

18. SANTOS, J. P.; MATTOS, A. P. Absenteísmodoença na prefeitura municipal de Porto Alegre, Rio Grande do Sul, Brasil. Revista Brasileira de Saúde Ocupacional, São Paulo, v. 121, n. 35, p. 148-156, 2010.

19. SANTOS, M. N.; MARQUES, A. C. Condições de saúde, estilo de vida e características de trabalho de professores de uma cidade do sul do Brasil. Ciência \& Saúde Coletiva, Rio de Janeiro, v. 18, n. 3, p. 837-846, 2013.

20. SILVA, L. S.; PINHEIRO, T. M. M.; SAKURAI, E. Perfil do absenteísmo em um banco estatal em Minas Gerais: análise do período de 1998 a 2003. Ciência \& Saúde Coletiva, Rio de Janeiro, v. 13, n. 2, p. 2049-2058, 2008.

21. CUNHA, J.; BLANK, V. L.; BOING, A. F. Tendência temporal de afastamento do trabalho em servidores públicos (1995-2005). Revista Brasileira de Epidemiologia, São Paulo, v. 12, n. 2, p. 226-236, 2009. 